\title{
An Investigation of International Journal usage by Iranian Medical Researchers
}

\author{
Ali Rashidi \\ Doctoral student, Department of Computing, London Metropolitan University, \\ 2-16 Eden Grove, London N7 8EA, \\ E-mail: a.rashidi@londonmet.ac.uk. \\ Bob Gilchrist \\ Professor of Statistics and Director of The Statistics, O.R. and Mathematics Research \\ Centre of London Metropolitan University, \\ 2-16 Eden Grove, London N7 8EA, E-mail: r.gilchrist@londonmet.ac.uk \\ Farhi Marir \\ Reader in Computer Science. 2-16 Eden Grove, London N7 8EA, E-mail: \\ f.marir@londonmet.ac.uk
}

\begin{abstract}
Knowledge of the extent to which information sources are used allows library managers to evaluate a library's collection and to make holding, archiving and purchasing decisions. The major objectives of this study were to identify a) the format of materials used in Iranian medical research, b) the age of cited items, c) the most frequently used journal titles which are critical to maintaining the core collection; and d) the half-life of the most cited journals. The results show the pattern of citation by type of media cited to have remained constant over the three years of the study, with journals being the most preferred format, accounting for $77.34 \%$ of all citations, followed by books $(18.67 \%)$ and theses $(1.5 \%)$. The results show that the age of cited materials varied from one type to the other. However there is a slight tendency to cite more recent issues within each type of media except web resources. The citation half-life of non- Iranian journals was 9 years whilst, on average, $50 \%$ of Iranian journals were cited within the last 6 years; however, the trend tends towards more recent issues. Web resources have the lowest half-life of three years. The 108 most cited internationally published journals (zone 1), providing 33\% of Iranian medical researchers information needs, were extracted on the basis of their citation frequency. These can be used by Iranian medical libraries as a baseline for subscription. Their corresponding quartiles of usage can be a criterion for storage policy.
\end{abstract}

Keywords: bibliometric indicators, core journal-subscription criteria and decisionmaking.

\section{Introduction}

Evaluation of citation patterns can help librarians to assess the extent to which information sources are used at the micro (obligations to librarians in specific libraries or librarians in specific difficulties) and macro (within a field) levels. These can be measured through performing library collection usage studies, by a user survey method or by checking library holdings against lists of core journals or other standardised reference sources.

Library collection usage studies require that data be collected regarding the number of times a particular resource has been accessed. Different libraries employ different methodologies for determining the rate of usage of a particular resource. However, all 
of these methods are labour-intensive, time-consuming and consequently draw precious resources away from other tasks. For example, in a closed system, access to resources would need to be requested explicitly with the data collected regarding the number of such requests can be used for usage analysis. Alternatively, in an open system, users are asked not to return resources to the shelves so that the number of times that the resource has been taken off the shelf can be monitored. With regard to checking of library holdings, an example is the use of the guide to reference books and journals (e.g. Brandon \& Hill, 1997; Balay, 1996) which suggest that a university medical faculty should hold, at least, a specific set of resources, including standard reference texts and journals.

In user survey methods, questionnaires or interviews with users or suggestion boxes can be employed to obtain data regarding the level of satisfaction of users and their specific requirements. Despite their high cost, being purely quantitative, the methods described above are limited in their evaluative scope. In other words, it is not possible to determine whether a borrowed or consulted item has been beneficial in any way. Therefore, there is a growing interest amongst libraries in the use of citation data as a decision making tool. Such information is particularly important in the case of expensive resources. At present, Iranian medical libraries purchase international journals at relatively high cost, in particular, after placing sanctions on Iran for its nuclear program by the Western countries which comprise subscription to electronic information resources such as Science Direct, Ovid and Web of Sciences. In this study, citations drawn from Iranian medical articles were used to evaluate the usage rate in Iran of internationally published journals.

\section{Literature Review}

Studies ranking the use of journals at many libraries have long been reported as aides in purchasing, cancellation, and storage decisions. Gross and Gross (1927) revealed that very few journals were cited often in the Journal of the American Chemical Society, whereas many journals were only cited once. Their findings coincide with Zipf's Law, which states that while a few items occur often, many items occur rarely (Wyllys, 1981). Libraries should be able to supply most of the information needs of their users with a small number of journals. Reviewing the rate of journal use is a known way of studying the effectiveness of the most expensive resources of the libraries, although it remains controversial. This process is routinely carried out in the libraries of developed countries (Masjedi, Kaykha, Chamyani \& Emami 2004). In the third world, however, the absence of bibliographic databases makes it impractical to measure the exact usage rate of information sources at the national level.

Citation analysis is now commonly used to determine what titles to buy, to cease, or to weed. Since the costs of journal subscriptions rose in the 1970s (Smith, 1981) the use of citation analysis was extended to determine the ratio of serials versus monographs that should be purchased (White, 1981). This use of citation analysis was employed by Kriz (1978) and has been followed by others, covering a broad range of subjects from Theology to Geology Devin \& Kellogg, 1990). An analysis of the bibliographic citations of research papers by Sylvia (1998) was used as one basis for Psychology journals selection and deselection in academic libraries. The findings confirmed that the most cost-effective and the most used materials were usually held by libraries. Titles that met these criteria and were not held were good candidates for 
new subscriptions. Likewise, the least cost-effective and least-used titles were candidates for cancellation.

In Iran, each year about $\$ 10 \mathrm{M}$ is spent on purchasing scientific journals for the country's medical universities by the Undersecretary of Research and Technology of the Ministry of Health and Medical Education (Masjedi, et al., 2004). Globally, each year, the subscription fee of medical journals increases by an average of $10 \%$. A study by Kean (2005) confirms that the price for U.S. periodicals increased by an average of $10.4 \%$ since 1999 . This figure is higher in Iran because of currency restrictions, American trade embargos (approximately $40 \%$ of core medical journals are published in the United States) and bureaucracy prohibiting direct purchase, resulting in much higher costs.

The Publishers Communication Group Inc. (PCG) (2005) who provide a detailed example of trends influencing journal subscription, cancellation and renewal for scholarly publishers, also studied trends in journal subscription renewal and cancellation. The findings show that between July 2004 and June 2005, $56 \%$ of the subscriptions included in the sample were cancelled. The PCG study highlighted a number of factors that influence an institution's decision to cancel a subscription. The PCG investigated why the specific subscription in question was cancelled in place of another subscription. When the topic was explored in greater detail, the librarians who had been contacted explained that because of reductions in collection budgets, they were forced to apply a number of cost-cutting exercises including usage studies, faculty surveys and the elimination of duplicate subscriptions. The tally of responses clearly demonstrated that, of the cancellations identified in their sample, $22 \%$ were motivated by low usage, $22 \%$ were due to electronic availability of the content and the library's budget prevented a renewal of $15 \%$ (Publishers Communications Group, Inc. 2005).

A study by Masjedi et al. (2004) showed that about two-thirds of the journals present in four educational and research centers in Tehran were used less than three times per month. In a similar library collection usage study performed on the international journals held at the libraries of Shaheed Beheshti University Medical School between 1990 and 1992, Sooresrafil (1993) found that over $31 \%$ of the journals were only consulted once in 3 months and $67 \%$ were not even used once in the same period.

Forouzi (1995), studied the internationally published journals usage rate in Tehran, Amir Kabir and Elm-o-Sanat universities in Iran and found that the maximum usage was 4 times for a time period of three months and the minimum cost per use was \$29.6. Meanwhile about $60 \%$ of the journals in Tehran University, $75 \%$ in Amir Kabir and $80 \%$ in Elmo-Sanat Universities were not even used once. In another study Kiani (1998) conducted in the libraries of Biomedical and Biophysical Research Centers of Tehran and Tarbiat Modarres Universities in Iran, and found that the average cost per use for each international journal was $\$ 43.75$ and $\$ 60.37$, respectively. Another survey performed on the libraries affiliated to the Medical School of Tehran University, Iran, showed that during the time period of 1994-1995 around $68.07 \%$ of international journals were not even used once (Sulaimani, 1999).

The literature on Iranian journal usage has centered on "off the shelf" studies. This method is unreliable since taking a resource off the shelf, or even borrowing, is not 
necessarily an indication that the resource has been used or useful. In addition, each of these studies is limited to one or two libraries, which may be informative at the individual library level, but do not provide a national picture.

In the present study, data have been collected and presented that allow citation criteria to be applied to investigate the usage rate of international journals cited by medical faculties. One such criterion is what is known as the journal half-life. This is the number of journal publication years, going back from the current year, that account for $50 \%$ of the total citations received by the cited journal in the current year. The data collected here facilitate the calculation the half-life of the most cited journals between 2002 and 2004. For decision-making purposes, the half-life is a further useful measure, as it provides an indication of the expected frequency of usage. As the literature ages, it receives fewer and fewer citations. The measure of half-life as the median age of cited sources has also been used to study the obsolescence of literature (Earle \& Vickery, 1969; Line, 1970). This phenomenon is known as "aging" or “obsolescence” Ya,sar Tonta and Yurdagül Ünal (2006).

The age of materials is useful in developing guidelines for retrospective collection development and storage. Whilst the half-life is a useful measure for helping with archiving decisions, 'citation frequency' is used as a decision making tool for journal acquisition. Such analysis is also made possible by the data collected in this study. Another useful measure includes material allocation formulae which often include a factor for the relative importance of journals versus monographs. Awareness of medical scholars' citation patterns may assist in developing such formulae.

The main aims of this study are to determine, a) the formats of materials used in Iranian medical research b) the age of cited items c) high use journal titles which are critical to maintaining the core collection d) the half-life of the most cited journals and to rank them accordingly.

\section{Method}

Raw data from an Iranian medical citation database, compiled mainly from printed sources, which was being developed by the author for the purpose conducting bibliometric studies such as this, were transferred into a spreadsheet and each record was tabulated on the basis of the consistent contextual elements of bibliographic information, such as (;) or (,). However, in many cases, due to the lack of consistency, many of the records were tabulated manually. The usage for each journal was then counted and tabulated according to frequency.

The citation half-life for each of the most cited titles was then calculated by working out the time taken to receive $50 \%$ of the total number of citations from the current publication year backwards. The 140,000 bibliographic citations in around 10,000 articles that appeared in the 90 Iranian medical journals published between 2002 and 2004 were analyzed and journals were grouped according to Bradford's Law (1948) of Scattering ${ }^{1}$. By applying Bradford's categories to foreign journals cited by the

\footnotetext{
1 Also known as the Pareto principle, the law of maldistribution, the law of the vital few and the principle of factor sparsity, the vital few and the trivial many, the $80 / 20$ rule states that for many phenomena, $80 \%$ of the consequences stem from $20 \%$ of the causes. The principle was first suggested by management thinker Joseph M. Juran, who named it after the Italian economist Vilfredo Pareto, who observed that $80 \%$ of income in Italy was received by $20 \%$ of the Italian population. Source:
} 
Iranian medical scholars, journals are grouped into three zones. Zone 1 consists of a few journals which have received the largest number of citations (the core cited journals), the second, larger group (Zone 2), has journals cited somewhat less frequently and Zone 3 contains a much larger set of journals cited relatively infrequently (candidates for substitution or cancellation).

\section{Results}

The result section begins with analyzing the age of cited materials from 2002 to 2004 followed by the investigation of different media usage by Iranian medical researchers. Internationally published medical journals having essential contribution in Iranian medical researchers' scientific production was then extracted along with their corresponding percentiles to help librarian for storage policy.

\section{Material Age}

Understanding the extent to which library users rely on older materials can be useful in determining which materials can be moved to remote storage (Ackerson, 2001). In this study for each year of the investigation, different types of cited media based on publication date were analyzed. The data in Tables 1, 2 and 3 show the age of media for different formats according to 25, 50 and 75 percentiles. Materials were grouped into 8 format categories for analysis: journals, books, reports, conference papers, web resources, theses, research projects and patents. Tables 1, 2 and 3 illustrate the age of different materials present from 2002 to 2004.

Table 1: Age of Materials in 2002

\begin{tabular}{|l|l|l|l|l|l|}
\hline & Valid & $\begin{array}{l}\mathbf{2 5}^{\text {th }} \\
\text { Percentiles }\end{array}$ & $\begin{array}{l}\mathbf{5 0}^{\text {th }} \\
\text { Percentiles }\end{array}$ & $\begin{array}{l}\mathbf{7 5}^{\text {th }} \\
\text { Percentiles }\end{array}$ & Half-life \\
\hline Foreign journals & 21922 & 1988 & 1994 & 1998 & 10 \\
\hline Farsi journals & 1152 & 1995 & 1998 & 2000 & 6 \\
\hline WWW & 136 & 1999 & 2001 & 2001.75 & 3 \\
\hline Foreign books & 5501 & 1991 & 1996 & 1999 & 8 \\
\hline Farsi books & 1109 & 1992 & 1996 & 1998 & 8 \\
\hline Foreign reports & 104 & 1990 & 1995 & 1999 & 9 \\
\hline Farsi reports & 59 & 1995 & 1998 & 1999 & 6 \\
\hline $\begin{array}{l}\text { Foreign } \\
\text { conferences }\end{array}$ & 93 & 1989 & 1994 & 1998 & 10 \\
\hline $\begin{array}{l}\text { Farsi } \\
\text { conferences }\end{array}$ & 400 & 1995 & 1998 & 2000 & 6 \\
\hline Foreign thesis & 25 & 1990.5 & 1995 & 1998 & 9 \\
\hline Farsi thesis & 458 & 1992 & 1995 & 1998 & 9 \\
\hline Foreign projects & 26 & 1991.75 & 1997 & 1999 & 7 \\
\hline Farsi projects & 115 & 1994 & 1997 & 1999 & 7 \\
\hline Patent & 1 & & & & \\
\hline
\end{tabular}

Trueswell, R. (1969). Some behavioral patterns of library users. The 80/20 rule. Wilson Library Bulletin, 46, 458-461. 
Table 2: Age of Materials in 2003

\begin{tabular}{|l|l|l|l|l|l|}
\hline & Valid & $\begin{array}{l}\text { 25th } \\
\text { Percentiles }\end{array}$ & $\begin{array}{l}\text { 50th } \\
\text { Percentiles }\end{array}$ & $\begin{array}{l}\text { 75th } \\
\text { Percentiles }\end{array}$ & Half-life \\
\hline Foreign journals & 32127 & 1989 & 1995 & 1999 & 9 \\
\hline Farsi journals & 1366 & 1996 & 1998 & 2000 & 6 \\
\hline WWW & 274 & 1998 & 2001 & 2002 & 3 \\
\hline Foreign books & 6763 & 1992 & 1997 & 2000 & 7 \\
\hline Farsi books & 1340 & 1992 & 1996 & 1999 & 8 \\
\hline Foreign reports & 129 & 1989.5 & 1996 & 1999 & 8 \\
\hline Farsi reports & 60 & 1996 & 1998 & 2000 & 6 \\
\hline $\begin{array}{l}\text { Foreign } \\
\text { conferences }\end{array}$ & 149 & 1988 & 1997 & 2000 & 7 \\
\hline $\begin{array}{l}\text { Farsi } \\
\text { conferences }\end{array}$ & 425 & 1996 & 1999 & 2000 & 5 \\
\hline Foreign thesis & 34 & 1987 & 1995 & 1997.25 & 9 \\
\hline Farsi thesis & 502 & 1993 & 1996 & 1998 & 8 \\
\hline Foreign projects & 19 & 1994 & 1997 & 1999 & 7 \\
\hline Farsi projects & 125 & 1992.5 & 1998 & 2000 & 6 \\
\hline Patent & 7 & 1951 & 1962 & 1985 & \\
\hline
\end{tabular}

Table 3: Age of Materials in 2004

\begin{tabular}{|l|l|l|l|l|l|}
\hline & Valid & $\begin{array}{l}\text { 25th } \\
\text { Percentiles }\end{array}$ & $\begin{array}{l}\text { 50th } \\
\text { Percentiles }\end{array}$ & $\begin{array}{l}\text { 75th } \\
\text { Percentiles }\end{array}$ & Half-life \\
\hline Foreign journals & 41929 & 1990 & 1996 & 2000 & 8 \\
\hline Farsi journals & 1588 & 1997 & 1999 & 2002 & 5 \\
\hline WWW & 370 & 2000 & 2001 & 2003 & 3 \\
\hline Foreign books & 7528 & 1993 & 1998 & 2000 & 6 \\
\hline Farsi books & 1013 & 1993 & 1997 & 2000 & 7 \\
\hline Foreign reports & 178 & 1991 & 1995.5 & 1999 & 8.5 \\
\hline Farsi reports & 72 & 1997 & 1999 & 2001 & 5 \\
\hline $\begin{array}{l}\text { Foreign } \\
\text { conferences }\end{array}$ & 221 & 1994 & 1999 & 2001 & 5 \\
\hline $\begin{array}{l}\text { Farsi } \\
\text { conferences }\end{array}$ & 356 & 1997 & 2000 & 2001 & 4 \\
\hline Foreign thesis & 52 & 1986.75 & 1996.5 & 1999.75 & 7.5 \\
\hline Farsi thesis & 647 & 1993 & 1996 & 1999 & 8 \\
\hline Foreign projects & 32 & 1992.25 & 1997.5 & 2000 & 6.5 \\
\hline Farsi projects & 111 & 1995 & 1998 & 2000 & 6 \\
\hline Patent & 9 & 1986 & 1991 & 1999.5 & \\
\hline
\end{tabular}

The results show that the age of materials cited varied from one type to the other. However there is a slight tendency to be published more recently within each type of material from 2002 to 2004 except web resources. Fifty percent of foreign journals cited were published within the previous 9 years whilst $50 \%$ of Farsi Journals on average were cited within the previous 6 years. As may be expected, the youngest items cited were web resources with an average of 3 years. Half of the foreign books cited ranged from 8-6 years old, while 50\% of the Farsi books were cited over a 
seven-year average. Half of the cited Farsi and foreign reports were published within the last 5 and 7.5 years, respectively. The half-life of cited conference papers tended to be more current than books, however there is a slight difference between the age of usage of foreign and Farsi conference papers (more than 7 years to 5 years, respectively). Half of Farsi and foreign theses cited were more than 8 years old. The practical application of these findings is that individual libraries could benefit of such information for archiving decisions depending upon the availability of space.

\section{Usage of information resources by Iranian medical researchers}

To investigate the types of information sources used by Iranian medical researchers and their preferred information formats several queries were written to extract relevant information. The data in Table 4 show the number and percentage of each type of information format cited by Iranian medical researchers between 2002 and 2004.

Table 4: Number and percentage of each type of information source usage between 2002 and 2004

\begin{tabular}{|l|l|l|l|l|l|l|l|}
\hline Years & $\mathbf{2 0 0 2}$ & $\mathbf{2 0 0 2}(\boldsymbol{\%})$ & $\mathbf{2 0 0 3}$ & $\mathbf{2 0 0 3}(\boldsymbol{\%})$ & $\mathbf{2 0 0 4}$ & $\mathbf{2 0 0 4}(\boldsymbol{\%})$ & $\begin{array}{l}\text { Average } \\
\text { percent }\end{array}$ \\
\hline Foreign journals & 21922 & 70.5 & 32127 & 74.2 & 41929 & 77.5 & 74.07 \\
\hline Farsi journals & 1152 & 3.7 & 1366 & 3.2 & 1588 & 2.9 & 3.27 \\
\hline WWW & 136 & 0.4 & 274 & 0.6 & 370 & 0.7 & 0.57 \\
\hline Foreign books & 5501 & 17.7 & 6763 & 15.6 & 7528 & 13.9 & 15.73 \\
\hline Farsi books & 1109 & 3.57 & 1340 & 3.09 & 1013 & 1.87 & 2.84 \\
\hline Foreign reports & 104 & 0.33 & 129 & 0.3 & 178 & 0.33 & 0.32 \\
\hline Farsi reports & 59 & 0.19 & 60 & 0.14 & 72 & 0.13 & 0.15 \\
\hline $\begin{array}{l}\text { Foreign } \\
\text { conferences }\end{array}$ & 93 & 0.3 & 149 & 0.34 & 221 & 0.41 & 0.35 \\
\hline Farsi conferences & 400 & 1.29 & 425 & 0.98 & 356 & 0.66 & 0.98 \\
\hline Foreign theses & 25 & 0.08 & 34 & 0.08 & 52 & 0.1 & 0.09 \\
\hline Farsi theses & 458 & 1.47 & 502 & 1.16 & 647 & 1.2 & 1.28 \\
\hline Foreign projects & 26 & 0.08 & 19 & 0.04 & 32 & 0.06 & 0.06 \\
\hline Farsi projects & 115 & 0.37 & 125 & 0.29 & 111 & 0.21 & 0.29 \\
\hline Patent & 1 & 0 & 7 & 0.02 & 9 & 0.02 & 0.01 \\
\hline Total & 31101 & 100 & 43320 & 100 & 54106 & 100 & 100 \\
\hline
\end{tabular}

The data in Table 4 show that more than $77 \%$ of the total citations were to Journals (74\% to foreign journals and 3.3\% to Iranian journals), more than 19\% to books, 0.6 $\%$ to web resources, $0.5 \%$ to reports, more than $1 \%$ to conference papers, and $1.3 \%$ to theses, $0.30 \%$ to research projects and just $0.01 \%$ were made to Patents. Of 9400 Foreign journals, 4532 (more than 48\%) occurred as one citation, the mean number of citations per article was 12 of which $75 \%$ were journals, $3.4 \%$ were conference proceedings and $6.4 \%$ were other formats such as books and electronic resources.

\section{The internationally published leading scientific medical journals cited in Iranian medical researchers papers}

In this study the half-life index is used to determine international journals' archiving policy. To this end, the publication dates of each cited journal were transferred to SPSS to divide the total of each title publication dates into four quartiles. 
Investigation based on the records of Iranian medical universities of their foreign journals subscriptions, available from the Ministry of Health and Medical Education in Iran, showed that $15 \%$ of Iranian medical universities libraries, all of which are based in Tehran, have very large collections as they are also responsible for supporting other libraries through such mechanisms as interlibrary loans. The database showed that $95 \%$ of the remaining $85 \%$ of medical libraries subscribed to 150-180 international journals. When all of the foreign journals that were cited by Iranian medical researchers were ranked in order of the number of citations received, Bradford's (1984) criterion was used to categories the journals into 3 zones. The top third most cited journals (zone 1) constituted the 108 journals that received 141 or more citations. Therefore 141 citations per three-year period served as the threshold to determine the international core journals set in medical sciences in Iran. However this threshold can be adjusted to meet the needs of individual universities, depending upon factors such as budgets.

The data in Table 5 lists the first twenty of the most cited non-Iranian journals and their corresponding percentiles. 
Table 5: The 20 most cited journals and their corresponding half-life

\begin{tabular}{|c|c|c|c|c|c|c|c|c|c|}
\hline Rank* & Journal & $\mathbf{N}$ & $\begin{array}{l}\text { Mode of } \\
\text { publication } \\
\text { date }\end{array}$ & $\begin{array}{l}25 \text { th } \\
\text { Perce } \\
\text { ntiles }\end{array}$ & $\begin{array}{l}50 \text { th } \\
\text { Perce } \\
\text { ntiles }\end{array}$ & $\begin{array}{l}75 \text { th } \\
\text { Perce } \\
\text { ntiles }\end{array}$ & $\begin{array}{l}\text { In } \\
\text { shelf }\end{array}$ & $\begin{array}{l}\text { Active } \\
\text { archive }\end{array}$ & $\begin{array}{l}\text { Passive } \\
\text { archive }\end{array}$ \\
\hline 1 & $\begin{array}{l}\mathrm{N} \text { ENGL J } \\
\text { MED }\end{array}$ & 1401 & 1995 & 1987 & 1993 & 1998 & 6 & 11 & 17 \\
\hline 2 & LANCET & 1121 & 1999 & 1985 & 1992 & 1997 & 7 & 12 & 19 \\
\hline 3 & JAMA & 803 & 1999 & 1987 & 1994 & 1998 & 6 & 10 & 17 \\
\hline 4 & BMJ & 769 & 2000 & 1985 & 1994 & 1998 & 6 & 10 & 19 \\
\hline 5 & $\begin{array}{l}\text { FERTIL } \\
\text { STERIL }\end{array}$ & 703 & 2001 & 1989 & 1996 & 1999 & 5 & 8 & 15 \\
\hline 6 & $\begin{array}{l}\text { AM J CLIN } \\
\text { NUTR }\end{array}$ & 625 & 2000 & 1988 & 1995 & 1999 & 5 & 9 & 16 \\
\hline 7 & $\begin{array}{l}\text { AM } \\
\text { OBSTET } \\
\text { GYNECOL }\end{array}$ & 615 & 1998 & 1987 & 1994 & 1998 & 6 & 10 & 17 \\
\hline 8 & $\begin{array}{l}\text { J CLIN } \\
\text { ENDOCRI } \\
\text { NOL } \\
\text { METAB }\end{array}$ & 605 & 1998 & 1988 & 1995 & 1999 & 5 & 9 & 16 \\
\hline 9 & $\begin{array}{l}\text { CIRCULAT } \\
\text { ION }\end{array}$ & 579 & 1998 & 1990 & 1995 & 1999 & 5 & 9 & 14 \\
\hline 10 & $\begin{array}{l}\text { OBSTET } \\
\text { GYNECOL }\end{array}$ & 566 & 1998 & 1990 & 1996 & 1999 & 5 & 8 & 14 \\
\hline 11 & $\begin{array}{l}\text { HUM } \\
\text { REPROD }\end{array}$ & 543 & 1998 & 1995 & 1997 & 2000 & 4 & 7 & 9 \\
\hline 12 & $\begin{array}{l}\text { DIABET } \\
\text { CARE }\end{array}$ & 537 & 1998 & 1994 & 1997 & 2000 & 4 & 7 & 10 \\
\hline 13 & J UROL & 528 & 1997 & 1988 & 1994 & 1998 & 6 & 10 & 16 \\
\hline 14 & PEDIATR & 512 & 1998 & $\begin{array}{l}1986 . \\
25\end{array}$ & 1994 & 1999 & 5 & 10 & 17.75 \\
\hline 15 & J PEDIATR & 484 & 1994 & 1985 & 1993 & 1998 & 6 & 11 & 19 \\
\hline 16 & $\begin{array}{l}\text { ANN } \\
\text { INTERN } \\
\text { MED }\end{array}$ & 462 & 1992 & 1985 & 1992 & 1997 & 7 & 12 & 19 \\
\hline 17 & $\begin{array}{l}\text { J BONE } \\
\text { AND } \\
\text { JOINT } \\
\text { SURG }\end{array}$ & 435 & 1990 & 1976 & 1987 & 1994 & 10 & 17 & 28 \\
\hline 18 & CANCER & 409 & 1998 & 1981 & 1990 & 1996 & 8 & 14 & 23 \\
\hline 19 & $\begin{array}{l}\mathrm{J} \\
\mathrm{MICROBIO} \\
\mathrm{L}\end{array}$ & 395 & 1998 & 1991 & 1996 & 1999 & 5 & 8 & 13 \\
\hline 20 & $\begin{array}{l}\text { GASTROE } \\
\text { NTROLOG } \\
\text { Y }\end{array}$ & 378 & 1998 & 1991 & 1996 & 1998 & 6 & 8 & 13 \\
\hline $21 *$ & $\ldots$ & & & & & & & & \\
\hline
\end{tabular}

*Ranked by number of citations. 
* The remaining titles are shown in Appendix 1.

These journals account for $12 \%$ of the total number of citations to non-Iranian journals. Appendix 1 contains a list of all 108 of the top third journals accounting for $33 \%$ of the total number of citations. These can be used for classification of the three chronological steps in weeding and archiving decisions. Again this threshold can be adjusted to meet the needs of individual universities, depending upon factors such as available space.

Over the course of the 3 years under investigations, 134,536 citations representing almost $100 \%$ of the total number of references have been analyzed from the 90 journals whose bibliographic data has been entered into the database. The majority of cited items were non-Iranian journal articles (95978 citations).

From the data in Table 5, the top 108 most cited journals are ranked in descending order. The table also lists first, second and third quartiles for each title. The 108 journals were able to provide for more than $33 \%$ of the information needs of Iranian medical researchers from 2002 to 2004.

The New England Journal of Medicine was the most cited journal, having been referenced a total of 1401 times. The second most-used journal, The Lancet was cited 1121 times.

As may be expected, the publication frequency might be related to the citation frequency. Therefore it is not surprising to see that the three weekly-published journals are ranked the highest, whereas monthly journals tend to be cited less frequently. It seems that the half-life of journals in a specific clinical discipline is relatively lower than those belonging to the general medicine.

Archiving and preservation refer to the processes and procedures required to ensure the content of journals remain accessible well into the future. Since library shelves run out of space, academic and research libraries of all types and sizes have to make decision on storage possibilities. To this end, based on quartiles of usage, the three steps "in shelf" (first quartile), "active archive" (second quartile or half life) and "passive archive" (third quartile) are proposed to preserve journals. In accordance with 25, 50 and 75 percent of quartiles libraries could decide for how long each journal could be kept in shelf or transferred to active or passive archive.

\section{Conclusion}

Evaluation of journals usage is a difficult but necessary task considering the wide range of choices available. Limited funding and space, as well as other factors, dictate the need for a carefully planned strategy of journal selection. Citation frequency can help deal with the series of decisions involved in the establishment and maintenance of an effective library collection.

In summary, although, publication strategies differ according to country and to scientific discipline, the Iranian medical sciences rely mostly on journal articles for research, as over $77 \%$ of all references were to journals. This number is slightly lower than the commonly used number of 80 percent for the sciences in general (Bowman, 
1990; Devin \& Kellogg, 1990). However the results support Haigh (1982) who indicates that third world scientists cite references primarily $(78 \%)$ from mainstream scientific literature. If the Iranian medical libraries decide to give priority to their funding situation, this figure can be used to determine the serials budget.

The pattern of citation by media remained constant over the three years of the study, with journals being the most preferred format of citation over the relatively short period under investigation. The results with regard to the age of cited materials show variations across the different types and there is a tendency to get younger within the age of each type of media from 2002 to 2004, except for web resources (see Tables 1, $2 \& 3)$.

The citation half-life of foreign journals is 9 years whilst $50 \%$ of Farsi journals on average were cited within the previous 6 years. These results are approximately in accordance with the study of Musser and Conkling (1996) and Kushkowski, Parsons $\&$ Wiese (2003) who found the majority of materials cited were less than eight years old. The lowest half-life belongs to web resources with3 years old. Further investigation might also determine the patterns of use of electronic resources, such as Internet sites or eBooks.

The 108 most cited internationally published journals, providing 33\% of Iranian medical researchers information needs, can be used by Iranian medical libraries as a baseline for subscription; along with their corresponding quartiles as a criterion for storage policy.

The list of internationally published journals belonging to the second zone consisting of 630 titles providing around a further $33 \%$ of information needs of Iranian medical researchers for the time frame under investigation.

\section{References}

Ackerson, Linda G. (2001) Is Age an Appropriate Criterion for Moving Journals to Storage. Collection Management 26 (3) 63-76.

Balay, R. (Ed.) (1996) Guide to reference books (11th Ed.) Chicago: American Library Association.

Bowman, M. S. (1990) Format citation patterns and their implications for collection development in research libraries. Collection Building 11(1) 2-8.

Bradford, S. C. (1948) Documentation. London: Crosby Lockwood,

Brandon AN, Hill DR (1997) Selected list of books and journals for the small medical library. Bulletin of the Association of Medical Librarians. 85 (2) 111-135.

Devin, R. B. \& Kellogg, M. (1990) The serial/monograph ratio in research libraries: Budgeting in light of citation studies. College \& Research Libraries, 51, 46-54.

Earle, P. \& Vickery, B. (1969) Social science literature use in the UK as indicated by citations. Journal of Documentation, 25, 123-141. 
Forouzi, S. (1995) Determining the relationship between the price and usage rate of periodical Latin journals of 1993 in the universities of Tehran, Amir Kabir and Elm$o$-Sanat. MSc Thesis in library and Information Sciences. Tehran. Tarbiat Modarres University.

Gross, P. L. K. \& Gross, E. M. (1927) College libraries and chemical education. Science, 66, 385-389.

Haigh MJ. (1982) Citation analysis of foreign sources in Japanese geographical serials. Scientometrics, 4 (3), 195-203.

Kean, G. (2005) 18th Annual Study of Journal Prices for Scientific and Medical Society Journals: 2005 Pricing Trends for U.S. Society Journals and Ten Recommendations for Pricing 2006 Volumes. JP, The Newsletter for Journal Publishers, 3. 15 July 2007: http://www.allenpress.com/static/newsletters/pdf/JP2005-03.pdf

Kiani , T. (1998) Studying the cost-usage of periodical Latin journals of biochemistry and biophysics in the library of IBB Institute of Tehran and Tarbiat Modarres Universities. MSc Thesis in Library and Information Sciences. Tehran. Tarbiat Modarres University.

Kriz, H. M. (1977) Citation counting and the future of engineering libraries. Engineering Education, 67, 707-710.

Kushkowski, D., Parsons, K.A., \& Wiese, W.H. (2003) Master's and Doctoral Thesis Citations: Analysis and Trends of a Longitudinal Study. Portal: Libraries and the Academy, 3(3), 459-479.

Line, M.B. (1970) The half-life of periodical literature: Apparent and real obsolescence. Journal of Documentation, 26, 46-54.

Masjedi M., Kaykha M., Chamyani F., \& Emami H. (2004) Evaluating the rate of international scientific journal use in the libraries of 53 four educational and research centers. Journal of Medical Education, 4(2), 53-57.

Musser, L R. \& Conkling, T.W. (1996) Characteristics of Engineering Citations. Science and Technology Libraries, 15 (4), 41-49.

Publisher's Communications Group, inc., 2005. 19 June 2008 : http://www.pcgplus.com/Resources/Trends2004.2005.pdf

Smith, L.C. (1981) Citation analysis. Library Trends, 30, 83-106.

Sooresrafil B. (1993) Determining the cost effectiveness of the main periodical journals in the central libraries of Shaheed Beheshti Medical University in 19901992. MSc Thesis in Library and Medical Information Sciences, Medical University of Iran. 
Sulaimani. (1999) Evaluation of non-Persian journals in the libraries affiliated to Tehran Medical University. MSc Thesis in Library and Medical Information Sciences. Medical University of Iran.

Sylvia, M. J. (1998) Citation analysis as an unobtrusive method for journal collection evaluation using psychology student research bibliographies. Collection Building, 17 (1), 20 - 28.

White, H. S. (1981) Strategies and alternatives in dealing with the serials management budget. In S. H. Lee (Ed.), Serials collection development: choices and strategies (pp. 31-32). Ann Arbor, MI: Pierian Press.

Wyllys, R. E. (1981) Empirical and Theoretical Bases of Zip's Law. Library Trends, 30 (1), 53-64.

Ya, sar T. \& Ünal, Y (2006) Scatter and Obsolescence of Journals Cited in Dissertations of Librarianship. Library \& Information Science Research, 28(2), 281296. 


\section{Appendix 1}

The 108 most cited journals and their corresponding quartiles

\begin{tabular}{|c|c|c|c|c|c|c|c|c|c|}
\hline Rank* & Journal & $\mathrm{N}$ & $\begin{array}{l}\text { Mode } \\
\text { of } \\
\text { public } \\
\text { ation } \\
\text { date }\end{array}$ & $\begin{array}{l}25 \text { th } \\
\text { Percent } \\
\text { iles }\end{array}$ & $\begin{array}{l}\text { 50th } \\
\text { Percent } \\
\text { iles }\end{array}$ & $\begin{array}{l}75 \text { th } \\
\text { Percent } \\
\text { iles }\end{array}$ & $\begin{array}{l}\text { In } \\
\text { shelf }\end{array}$ & $\begin{array}{l}\text { Active } \\
\text { archive }\end{array}$ & $\begin{array}{l}\text { Passive } \\
\text { archive }\end{array}$ \\
\hline 1 & N ENGL J MED & 1401 & 1995 & 1987 & 1993 & 1998 & 6 & 11 & 17 \\
\hline 2 & LANCET & 1121 & 1999 & 1985 & 1992 & 1997 & 7 & 12 & 19 \\
\hline 3 & JAMA & 803 & 1999 & 1987 & 1994 & 1998 & 6 & 10 & 17 \\
\hline 4 & BMJ & 769 & 2000 & 1985 & 1994 & 1998 & 6 & 10 & 19 \\
\hline 5 & FERTIL STERIL & 703 & 2001 & 1989 & 1996 & 1999 & 5 & 8 & 15 \\
\hline 6 & $\begin{array}{lll}\text { AM } & \text { J } & \text { CLIN } \\
\text { NUTR } & \\
\end{array}$ & 625 & 2000 & 1988 & 1995 & 1999 & 5 & 9 & 16 \\
\hline 7 & $\begin{array}{l}\text { AM J OBSTET } \\
\text { GYNECOL }\end{array}$ & 615 & 1998 & 1987 & 1994 & 1998 & 6 & 10 & 17 \\
\hline 8 & $\begin{array}{l}\text { J CLIN } \\
\text { ENDOCRINOL } \\
\text { METAB }\end{array}$ & 605 & 1998 & 1988 & 1995 & 1999 & 5 & 9 & 16 \\
\hline 9 & CIRCULATION & 579 & 1998 & 1990 & 1995 & 1999 & 5 & 9 & 14 \\
\hline 10 & $\begin{array}{l}\text { OBSTET } \\
\text { GYNECOL }\end{array}$ & 566 & 1998 & 1990 & 1996 & 1999 & 5 & 8 & 14 \\
\hline 11 & HUM REPROD & 543 & 1998 & 1995 & 1997 & 2000 & 4 & 7 & 9 \\
\hline 12 & DIABET CARE & 537 & 1998 & 1994 & 1997 & 2000 & 4 & 7 & 10 \\
\hline 13 & J UROL & 528 & 1997 & 1988 & 1994 & 1998 & 6 & 10 & 16 \\
\hline 14 & PEDIATR & 512 & 1998 & $\begin{array}{l}1986.2 \\
5\end{array}$ & 1994 & 1999 & 5 & 10 & 17.75 \\
\hline 15 & J PEDIATR & 484 & 1994 & 1985 & 1993 & 1998 & 6 & 11 & 19 \\
\hline 16 & $\begin{array}{ll}\text { ANN } & \text { INTERN } \\
\text { MED } & \end{array}$ & 462 & 1992 & 1985 & 1992 & 1997 & 7 & 12 & 19 \\
\hline 17 & $\begin{array}{l}\text { J BONE AND } \\
\text { JOINT SURG }\end{array}$ & 435 & 1990 & 1976 & 1987 & 1994 & 10 & 17 & 28 \\
\hline 18 & CANCER & 409 & 1998 & 1981 & 1990 & 1996 & 8 & 14 & 23 \\
\hline 19 & $\begin{array}{l}\text { J CLIN } \\
\text { MICROBIOL }\end{array}$ & 395 & 1998 & 1991 & 1996 & 1999 & 5 & 8 & 13 \\
\hline 20 & $\begin{array}{l}\text { GASTROENTRO } \\
\text { LOGY }\end{array}$ & 378 & 1998 & 1991 & 1996 & 1998 & 6 & 8 & 13 \\
\hline 21 & CHEST & 371 & 1997 & 1988 & 1993 & 1998 & 6 & 11 & 16 \\
\hline 22 & $\begin{array}{l}\text { ARCH INTERN } \\
\text { MED }\end{array}$ & 370 & 1997 & $\begin{array}{l}1988.7 \\
5\end{array}$ & 1994 & 1998 & 6 & 10 & 15.25 \\
\hline 23 & AM J MED & 365 & 1999 & 1983 & 1991 & 1998 & 6 & 13 & 21 \\
\hline 24 & NATURE & 359 & 1970 & 1976 & 1985 & 1994 & 10 & 19 & 28 \\
\hline 25 & $\begin{array}{l}\text { ANESTH } \\
\text { ANALG }\end{array}$ & 350 & 2000 & 1990 & 1995 & 1999 & 5 & 9 & 14 \\
\hline 26 & $\begin{array}{l}\text { PROC NATL } \\
\text { ACAD SCI USA }\end{array}$ & 345 & 1996 & 1988 & 1993 & 1997 & 7 & 11 & 16 \\
\hline 27 & BRAIN RES & 325 & 1995 & 1987 & 1993 & 1997 & 7 & 11 & 17 \\
\hline
\end{tabular}




\begin{tabular}{|c|c|c|c|c|c|c|c|c|c|}
\hline 28 & $\begin{array}{ll}\text { AM } & \mathrm{J} \\
\text { EPIDEMIOL }\end{array}$ & 318 & 1998 & 1986 & 1993 & 1998 & 6 & 11 & 18 \\
\hline 29 & $\begin{array}{l}\text { ANN THORAC } \\
\text { SURG }\end{array}$ & 315 & 1996 & 1991 & 1995 & 1998 & 6 & 9 & 13 \\
\hline 30 & AM J CARDIOL & 314 & 1998 & 1988 & 1994 & 1998 & 6 & 10 & 16 \\
\hline 31 & $\begin{array}{lr}\text { AM } & \text { J } \\
\text { GASTROENTRO } \\
\text { LOGY }\end{array}$ & 312 & 1999 & 1993 & 1998 & 2000 & 4 & 6 & 11 \\
\hline 32 & SCIENCE & 298 & 1998 & 1982 & 1990 & 1996 & 8 & 14 & 22 \\
\hline 33 & $\begin{array}{l}\text { ANESTHESIOL } \\
\text { OGY }\end{array}$ & 282 & 1992 & 1986 & 1992 & 1996 & 8 & 12 & 18 \\
\hline 34 & AM J PHYSIOL & 270 & 1992 & 1986 & 1993 & 1997 & 7 & 11 & 18 \\
\hline 35 & INFECT IMMUN & 270 & 1995 & 1988 & 1993 & 1998 & 6 & 11 & 16 \\
\hline 36 & J INFECT DIS & 269 & 1991 & 1987 & 1993 & 1998 & 6 & 11 & 17 \\
\hline 37 & RADIOLOGY & 265 & 1991 & 1985 & 1991 & 1996 & 8 & 13 & 19 \\
\hline 38 & $\begin{array}{ll}\text { ARCH } & \text { DIS } \\
\text { CHILD } & \end{array}$ & 264 & 1994 & 1984 & 1992 & 1997 & 7 & 12 & 20 \\
\hline 39 & BLOOD & 263 & 1998 & 1991 & 1995 & 1998 & 6 & 9 & 13 \\
\hline 40 & KIDNEY INT & 256 & 1999 & 1990 & 1995 & 1999 & 5 & 9 & 14 \\
\hline 41 & $\begin{array}{l}\text { BR J OBSTET } \\
\text { GYNECOL }\end{array}$ & 253 & 1998 & 1988 & 1995 & 1999 & 5 & 9 & 16 \\
\hline 42 & J IMMUNOL & 250 & 2000 & 1988 & 1995 & 1999 & 5 & 9 & 16 \\
\hline 43 & DIABETES & 247 & 1991 & 1985 & 1991 & 1996 & 8 & 13 & 19 \\
\hline 44 & SPINE & 246 & 1995 & 1989 & 1994 & 1997 & 7 & 10 & 15 \\
\hline 45 & CLIN ORTOP & 245 & 1996 & 1982 & 1989 & 1995.5 & 8.5 & 15 & 22 \\
\hline 46 & GUT & 233 & 1999 & 1991 & 1996 & 1999 & 5 & 8 & 13 \\
\hline 47 & J BIOL CHEM & 228 & 1993 & 1983 & 1992 & 1998 & 6 & 12 & 21 \\
\hline 48 & J CLIN INVEST & 227 & 1997 & 1983 & 1991 & 1995 & 9 & 13 & 21 \\
\hline 49 & Am J Psychiatry & 224 & 1998 & 1986 & 1992 & 1998 & 6 & 12 & 18 \\
\hline 50 & $\begin{array}{l}\text { CLIN } \\
\text { DIN }\end{array}$ & 223 & 1997 & 1995 & 1997 & 1999 & 5 & 7 & 9 \\
\hline 51 & J NEUROSURG & 223 & 2002 & 1983 & 1991 & 1998 & 6 & 13 & 21 \\
\hline 52 & $\begin{array}{l}\text { AM J TROP } \\
\text { MED HYG }\end{array}$ & 220 & 1999 & $\begin{array}{l}1981.2 \\
5\end{array}$ & 1992 & 1997 & 7 & 12 & 22.75 \\
\hline 53 & J ENDODON & 220 & 1992 & 1986 & 1992 & 1996 & 8 & 12 & 18 \\
\hline 54 & PAIN & 213 & 1995 & 1989 & 1993 & 1997 & 7 & 11 & 15 \\
\hline 55 & $\begin{array}{l}\text { TRANSPLANTA } \\
\text { TION }\end{array}$ & 213 & 2000 & 1994 & 1997 & 2000 & 4 & 7 & 10 \\
\hline 56 & $\begin{array}{l}\text { LARYNGOSCO } \\
\text { PE }\end{array}$ & 211 & 2000 & 1986 & 1994 & 1999 & 5 & 10 & 18 \\
\hline 57 & J NUTR & 210 & 2000 & 1994 & 1998 & 2000 & 4 & 6 & 10 \\
\hline 58 & $\begin{array}{l}\text { OSTEOPOROSIS } \\
\text { INT }\end{array}$ & 209 & 2001 & 1996 & 1999 & 2001 & 3 & 5 & 8 \\
\hline 59 & STROKE & 206 & 1999 & $\begin{array}{l}1990.7 \\
5\end{array}$ & 1997 & 1999 & 5 & 7 & 13.25 \\
\hline 60 & NEUROLOGY & 201 & 1996 & 1989 & 1995 & 1998 & 6 & 9 & 15 \\
\hline 61 & J ADV NURS & 197 & 1998 & 1994 & 1998 & 2000 & 4 & 6 & 10 \\
\hline 62 & BR J ANESTH & 196 & 2000 & 1987 & 1993 & 1998 & 6 & 11 & 17 \\
\hline
\end{tabular}




\begin{tabular}{|c|c|c|c|c|c|c|c|c|c|}
\hline 63 & $\begin{array}{l}\text { J PROSTHET } \\
\text { DENT }\end{array}$ & 193 & 1989 & 1982.5 & 1988 & 1994 & 10 & 16 & 21.5 \\
\hline 64 & $\begin{array}{l}\mathrm{J} \text { AM COLL } \\
\text { CARDIOL }\end{array}$ & 192 & 1998 & 1993 & 1997 & 1999 & 5 & 7 & 11 \\
\hline 65 & $\begin{array}{ll}\text { EUR } & \mathrm{J} \\
\text { PHARMACOL }\end{array}$ & 191 & 1999 & 1988 & 1995 & 1999 & 5 & 9 & 16 \\
\hline 66 & J TRAUMA & 191 & 1998 & 1986 & 1993 & 1997 & 7 & 11 & 18 \\
\hline 67 & VACCINE & 188 & 2001 & 1994 & 1997.5 & 2000 & 4 & 6.5 & 10 \\
\hline 68 & $\begin{array}{l}\text { J THORAC } \\
\text { CARDIOVASC } \\
\text { SURG }\end{array}$ & 185 & 1995 & 1984 & 1992 & 1996 & 8 & 12 & 20 \\
\hline 69 & \begin{tabular}{ll}
\multicolumn{3}{l}{ TRANSACTION } \\
S OF THE \\
ROYAL \\
SOCIETY \\
TROPICAL \\
MEDICINE \\
HYND \\
HYIENE
\end{tabular} & 185 & 1995 & 1985 & 1992 & 1997 & 7 & 12 & 19 \\
\hline 70 & Anaesthesia & 185 & 1992 & 1988 & 1992 & 1997 & 7 & 12 & 16 \\
\hline 71 & $\begin{array}{l}\mathrm{J} \text { PHARMACOL } \\
\text { EXP THER }\end{array}$ & 184 & 1997 & 1984 & 1990.5 & 1997 & 7 & 13.5 & 20 \\
\hline 72 & AJR & 184 & 1992 & $\begin{array}{l}1986.2 \\
5\end{array}$ & 1993 & 1998 & 6 & 11 & 17.75 \\
\hline 73 & J Periodontol & 184 & 1992 & 1982 & 1990 & 1996 & 8 & 14 & 22 \\
\hline 74 & $\begin{array}{l}\text { AM J PUBLIC } \\
\text { HEALTH }\end{array}$ & 180 & 1994 & 1988 & 1994 & 1997 & 7 & 10 & 16 \\
\hline 75 & $\begin{array}{l}\text { PEDIATR } \\
\text { INFECT DIS J }\end{array}$ & 179 & 2000 & 1992 & 1997 & 2000 & 4 & 7 & 12 \\
\hline 76 & $\begin{array}{l}\text { CLIN } \\
\text { ENDOCRINOL }\end{array}$ & 175 & 1995 & 1990 & 1994 & 1998 & 6 & 10 & 14 \\
\hline 77 & CANCER RES & 173 & 1990 & 1986 & 1991 & 1997 & 7 & 13 & 18 \\
\hline 78 & HEPATOLOGY & 172 & 2000 & 1995 & 1998 & $\begin{array}{l}2000.7 \\
5\end{array}$ & 3.25 & 6 & 9 \\
\hline 79 & ACTA PEDIATR & 167 & 1999 & 1994 & 1997 & 1999 & 5 & 7 & 10 \\
\hline 80 & CLIN CHEM & 166 & 1972 & 1982 & 1990 & 1996 & 8 & 14 & 22 \\
\hline 81 & $\begin{array}{l}\text { ARCH GEN } \\
\text { PSYCHIATR }\end{array}$ & 165 & 1994 & 1983 & 1991 & 1996 & 8 & 13 & 21 \\
\hline 82 & AM J SURG & 165 & 1996 & 1982 & 1992 & 1996 & 8 & 12 & 22 \\
\hline 83 & INT J PHARM & 163 & 1995 & 1991 & 1996 & 2000 & 4 & 8 & 13 \\
\hline 84 & $\begin{array}{l}\mathrm{J} \\
\text { ETHNOPHARM } \\
\text { ACOL }\end{array}$ & 162 & 2000 & $\begin{array}{l}1992.7 \\
5\end{array}$ & 1998 & 2000 & 4 & 6 & 11.25 \\
\hline 85 & $\begin{array}{lr}\text { ORAL } & \text { SURG } \\
\text { ORAL } & \text { MED } \\
\text { ORAL } & \text { PATHOL }\end{array}$ & 161 & 1994 & 1983.5 & 1989 & 1992 & 12 & 15 & 20.5 \\
\hline 86 & $\begin{array}{ll}\text { BR } & \text { J } \\
\text { PSYCHIATRY }\end{array}$ & 160 & 1990 & $\begin{array}{l}1985.2 \\
5\end{array}$ & 1991.5 & 1996 & 8 & 12.5 & 18.75 \\
\hline 87 & DIABETOLOGI & 160 & 1992 & 1985 & 1993 & 1997 & 7 & 11 & 19 \\
\hline
\end{tabular}




\begin{tabular}{|c|c|c|c|c|c|c|c|c|c|}
\hline & $\mathrm{A}$ & & & & & & & & \\
\hline 88 & BR J SURG & 156 & 1992 & 1982 & 1990.5 & 1996 & 8 & 13.5 & 22 \\
\hline 89 & LIFE SCI & 155 & 1992 & 1985 & 1993 & 1999 & 5 & 11 & 19 \\
\hline 90 & BURNS & 154 & 1998 & 1995 & 1998 & 2000 & 4 & 6 & 9 \\
\hline 91 & ANN SURG & 153 & 1998 & 1974.5 & 1988 & 1997 & 7 & 16 & 29.5 \\
\hline 92 & $\begin{array}{l}\text { ARCH } \quad \text { PHYS } \\
\text { MED REHAB }\end{array}$ & 152 & 1992 & 1988 & 1992 & 1998 & 6 & 12 & 16 \\
\hline 93 & $\begin{array}{l}\text { J PEDIATR } \\
\text { SURG }\end{array}$ & 152 & 2001 & $\begin{array}{l}1990.2 \\
5\end{array}$ & 1997 & 2000 & 4 & 7 & 13.75 \\
\hline 94 & OPHTHALMOL & 152 & 1999 & 1988 & 1995 & 1999 & 5 & 9 & 16 \\
\hline 95 & METABOLISM & 152 & 1998 & 1986 & 1994 & 1998 & 6 & 10 & 18 \\
\hline 96 & $\begin{array}{l}\text { NEPHROL DIAL } \\
\text { TRANSPLANT }\end{array}$ & 152 & 1999 & 1995 & 1998 & $\begin{array}{l}2000.7 \\
5\end{array}$ & 3.25 & 6 & 9 \\
\hline 97 & ARCH SURG & 149 & 1996 & 1983 & 1991 & 1997 & 7 & 13 & 21 \\
\hline 98 & $\begin{array}{l}\text { ATHEROSCLER } \\
\text { OSIS }\end{array}$ & 149 & 2000 & 1991 & 1996 & 1999 & 5 & 8 & 13 \\
\hline 99 & DIABET MED & 149 & 1998 & 1995 & 1998 & 2000 & 4 & 6 & 9 \\
\hline 100 & $\begin{array}{l}\text { ANN N Y ACAD } \\
\text { SCI }\end{array}$ & 149 & 1998 & 1990 & 1997 & 1999 & 5 & 7 & 14 \\
\hline 101 & AM HEART J & 149 & 2000 & 1989 & 1994 & 1999 & 5 & 10 & 15 \\
\hline 102 & J RHEUMATOL & 148 & 1997 & 1991 & 1995 & 1998 & 6 & 9 & 13 \\
\hline 103 & J EXP MED & 148 & 1992 & $\begin{array}{l}1982.2 \\
5\end{array}$ & 1992 & 1998 & 6 & 12 & 21.75 \\
\hline 104 & $\begin{array}{l}\text { AM REV RESP } \\
\text { DIS }\end{array}$ & 146 & 1989 & 1981 & 1987.5 & 1991 & 13 & 16.5 & 23 \\
\hline 105 & $\begin{array}{l}\text { J AM ACAD } \\
\text { DERMATOL }\end{array}$ & 146 & 1996 & $\begin{array}{l}1990.7 \\
5\end{array}$ & 1995 & 1998 & 6 & 9 & 13.25 \\
\hline 106 & UROLOGY & 146 & 2002 & $\begin{array}{l}1989.7 \\
5\end{array}$ & 1995 & 1999 & 5 & 9 & 14.25 \\
\hline 107 & $\begin{array}{l}\text { ENDOCRINOLO } \\
\text { GY }\end{array}$ & 144 & 2001 & 1984 & 1992 & 1998 & 6 & 12 & 20 \\
\hline 108 & $\begin{array}{l}\text { ACTA OBSTET } \\
\text { GYNECOL } \\
\text { SCAND }\end{array}$ & 141 & 1997 & 1992 & 1997 & 2000 & 4 & 7 & 12 \\
\hline
\end{tabular}

